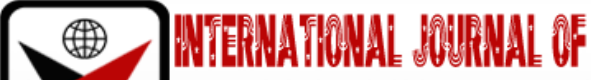 \\ בmas
}

ISSN 2278-0211 (Online)

\section{School Boards' Contributions on Community Secondary School Teachers' Level of Motivation in Tanzania}

\begin{tabular}{c}
\hline Consumata Kunguse \\
MA Student, Department of Education, Mwenge Catholic University, Tanzania \\
Muteti Catherine Mueni \\
Lecturer, Department of Education, Mwenge Catholic University, Tanzania \\
Evans Okendo Ogoti \\
Senior Lecturer, Department of Education, Mwenge Catholic University, Tanzania
\end{tabular}

\begin{abstract}
:
The aim of this study was to investigate the contribution of school boards on teachers' levels of motivation in community secondary schools in Moshi District Council, Tanzania. This was pursued under the research questions; which were to investigate the extent to which the school boards perform different teacher motivational strategies, the perceptions of teachers towards how the school boards motivates them, challenges and suggestions on how to improve the contribution of school boards on teachers' levels of motivation and to determine the ways of overcoming the challenges in order to improve the performance of school boards on teachers' levels of motivation. The study was guided by Motivation-Hygiene Theory of (1959). The researcher adopted concurrent design under the mixed methods approach which enabled the collection of qualitative and quantitative data at the same time for the purpose of understanding the problem in detail. The study targeted all heads of schools, teachers and board members from community secondary schools in Moshi District Council. Probability and nonprobability sampling techniques were used to select the study sample which consisted of 100 teachers, 10 heads of schools and 10 members of school boards to make a total number of 120 respondents. Questionnaires, document analysis schedule and interview guides were used to collect data. Descriptive and inferential statistics were used to analyze the quantitative data, frequencies, percentages and means. The hypothesis was tested by using independent sample t-test at 95\% confidence level. Qualitative data were analyzed thematically. The study found out that the school boards do not do most of the practices that would contribute to teachers' levels of motivation. Also teachers were found to have negative perception towards how the school boards motivate them. Results of hypothesis testing indicated no significant difference in the perception mean scores of male and female teachers whereas all of them felt to be demotivated by the school boards ( $p$-value $=0.421$ ). The findings revealed that lack of funds was pointed out as the main challenge for failure of the school boards to motivate teachers. The study recommended for proper fund raising so as to make the schools to have adequate budget for teachers motivation so as to enable teachers to give out their best.
\end{abstract}

Keywords: Contribution, perception, motivation, school board, community secondary schools

\section{Introduction}

Motivation of any kind has been found to have significant effect on the job performance of workers whereas workers who are motivated demonstrate higher job performance than the ones who are less motivated (Bernaus\& Gardner, 2008; Atkinson, 2010; Davis \& Elson, 2010). Though the ethical conduct for teachers in Tanzania sees the teaching profession as a vocation and not a mare gainful job (Kuhanga, 1997), research show that there is a significant difference in the job performance of highly motivated and less motivated teachers whereby the ones who are motivated demonstrate high job performance compared to those who are less motivated. Therefore, teachers as other workers need to be motivated for them to become more committed to the teaching profession.

Motivation has been defined differently by different scholars; for instance, Scott (2013) sees motivation as a planned managerial process which stimulates people to work to the best of their capabilities. Therefore, motivation is considered as the process of stimulating people to actions to accomplish desired goals. A number of scholars have shown the existence of positive correlation between teacher motivation and their job performance (Reizer et al, 2019; Onanda, 2015). Therefore, when thinking about improving the quality of education offered in schools, it is important also to think about the best ways of motivating the teachers. This is because when teachers are motivated, they feel to be appreciated and hence they are likely to put more efforts in the teaching process.

Among the factors that may contribute to teacher motivation include working conditions, school facilities and friendly working environments (Narimawati, 2003). This implies that the working environment for teachers should be positive so as to enables them to meet their daily needs. Supportive environment motivates teachers to demonstrate their 
best knowledge and skills in the teaching profession while unsupportive environment demotivates teachers (Kinnunen (2006). Teacher motivation is therefore not limited to monetary incentives but extends to recognition of one's job, commitment and experience (Saari\& Judge, 2004). It may also include different activities that bring about positive emotional state resulting from the appraisal of one's job.

Due to its contribution to students' academic success, the issue of teacher' level of motivation has received significant attention in majority of educational institutions from various countries around the world. Countries like Australia, England, Netherlands and the USA have developed guidelines for teachers' motivation. In the United Kingdom for example, teacher motivation is considered in terms of high level of professional autonomy, the feeling that they benefit the society and enjoy good relations (Van Der Voort and Wood, 2014; Dervarios\& O’Brien 2014). This also proves that teacher motivation is not limited to giving money to teachers but creating concussive environment in which teachers may feel being respected, valued and recognized by the society for the role they play in fighting ignorance.

At school level, the school management is responsible for ensuring teacher motivation (MOEC, 2004). According to Stoll and Fink (1996), the level of teacher motivation depends highly on the effectiveness of the school management. The school management is therefore responsible for setting up the school structure that will lead to teacher motivation. If the school setup is not well organized, teachers will be less motivated and can lose hope and sense of professional responsibility. Therefore, it is important for the school management to act as an impetus for teacher motivation by using different incentives in order to raise school performance (Hassan and Sheriff, 2006). From this view, the school management needs to plan and implement different teacher motivation strategies to make teachers more committed in the teaching profession.

While executing its responsibilities, the school management is assisted by the school board. According to Gale (2002), school boards are established to ensure the provision of quality education in schools. Moreover, the Education Act number 25 of 1978 in Tanzania recognizes a school board as a group of not more than thirteen members whose major purpose is to ensure proper management of the schools (URT, 1995). In Tanzania, the minister of education together with the education commissioner is responsible for setting principles necessary for the establishment of school boards (URT, 1995). To ensure a good link between the school board and the school management, the head of school is the secretary of the school board. Therefore, he or she is expected to document and ensure the implementation of recommendations suggested by the school board.

Among the duties of school boards include providing positive reinforcement to best performing teachers and students for the purpose of encouraging them, increasing commitment among teachers and students and improving the quality of education (URT, 1995). This duty calls for the school board in collaboration with the school management to design and implement different motivation schemes to teachers for the purpose of increasing their commitment. It is important to motivate the teachers since research shows the existence of a positive strong correlation between the level of motivation and teacher commitment in the teaching professional (Hassan and Sheriff, 2006). It was important therefore to conduct a study to determine different motivation strategies that are implemented by the school board and the extent to which such strategies motivate teachers.

Studies across the world show some challenges facing the school boards in executing their responsibility of motivating teachers. In the United Kingdom for instance, school boards have abandoned issues related to teacher motivation instead they have shifted attention to managerial and disciplinary issues (Srivastava\& Bhatia, 2013). Similarly, in Turkey teachers have been complaining of not being recognized despite the sacrifice they make in the teaching profession (Süleyman, 2015). In Nigeria infective communication between the school board and the teachers has been reported. Teachers have been complaining for not having representatives in the school board and therefore their needs are not well discussed during the board meetings (Okorie and Usulor, 2016). Infective communication between the board and teachers may affect the effectiveness of school board in performing its activities including motivating teachers. In Tanzania however, there is limited literature on how well the school boards contribute to teachers' level of motivation.

It is important to consider teachers level of motivation as long as there is a strong positive strong relationship between teachers' level of motivation and students' academic achievement (Melchiory, 2015; Omondi, 2013; Mukumbi\&Kabeta, 2010). By considering the form four national examination results from a sample of 10 secondary schools from in Moshi district, students' performance in these schools generally poor whereby majority of the students scored between division four and division zero, this situation shows that there is a problem than needs to be addressed for the purpose of improving the quality of education offered in these schools. The summary of students' results in selected 10 community secondary schools in Moshi district council is presented in figure 1. 


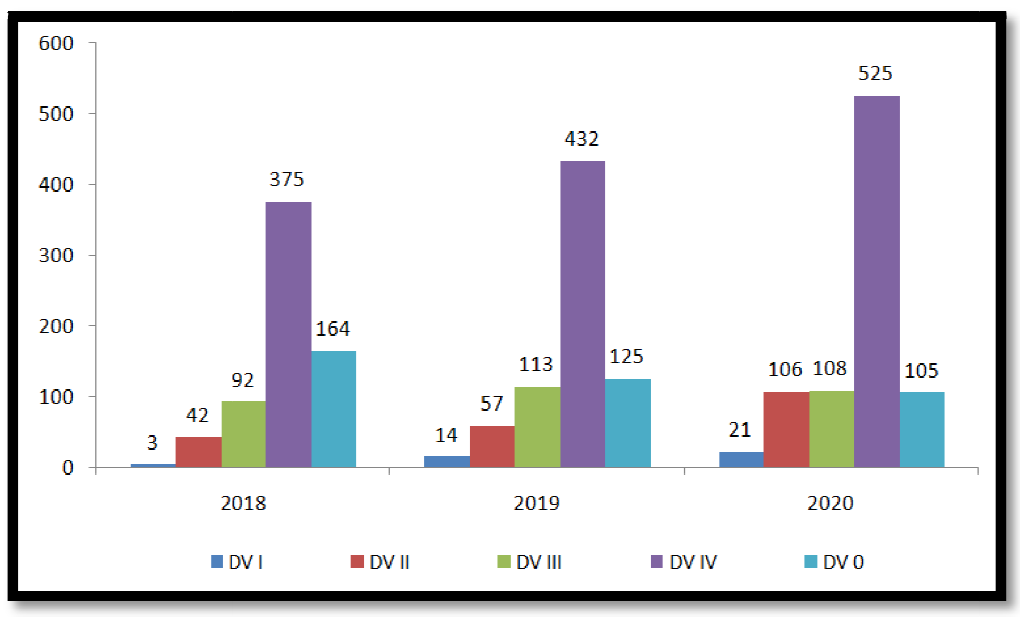

Figure 1: Summary of Students Results from Ten Secondary Schools (2018 - 2020)

Source (NECTA, 2018, 2019, 2020)

As presented in figure 1 majority of students in the ten selected community secondary schools in Moshi District Council nearly failed the 2018, 2019 and 2020 national examinations. Scholars have come out with a number of factors contributing to such poor performance. However, little attention has been paid on how the school boards as part of the school management motivates teachers despite the existing relationship between teachers' level of motivation and students' academic achievements. Therefore, there was a need for the current study to be conducted to determine the contribution of school boards on teachers' level of motivation in community secondary schools in Moshi District Council.

\subsection{Statement of the Problem}

There has been a concern on secondary school teachers' motivation in Tanzania. Motivation to teachers is very essential practice as it improves performance of the teacher in teaching and learning process (Lyimo, 2014; Musa, 2014). The school boards has a role to play in supporting development and implementation of teacher motivation schemes in the wider public secondary schools (Chua and Mosha, 2015). However, there are growing concerns that teachers in Tanzania are increasingly de-motivated, which is reflected in deteriorating teaching performance and learning outcomes (Mbope, 2015). This has been linked to the poor performance of students in national examinations.

Regardless of the government effort towards durable solutions to motivate public secondary school teachers, (Admassie, 2017), school boards were reported to lack of essential skills and awareness to determine their roles toward motivating teachers to improve their working performance (Remijan, (2014). Several studies like those of (Lu \& Hallinger, 2018; Lyimo, 2014; Mathipa et al., 2014; Raynham, 2016; Sava \& Orodho, 2014) have paid much attention to the contributions of school management toward improving students' academic performance, influence of school management in motivating students and school management team instructional leadership role. However, the researchers have not explained the influence of school board on teachers' level of motivation. Therefore, this study investigated the contribution of school board on teachers' level of motivation in community secondary schools in Tanzania by taking Moshi district as the study area.

\subsection{Research Questions}

- How do the school board practices contribute to teachers' level of motivation in community secondary schools Moshi District?

- What are the perceptions of teachers on school boards' contribution to their level of motivation in community secondary schools Moshi District?

\subsection{Research Hypothesis}

There is a significant difference in the mean perception of male and female teachers on the contribution of school boards to their level of motivation.

\subsection{Theoretical Framework}

The study was guided by Hertzberg's Motivation-Hygiene Theory. Frederick Hertzberg (1959) who was clinical psychologist and pioneer of job enrichment is regarded as one of the great original thinkers in management and motivational theory. The theory states that there are certain factors in the work place that cause job satisfaction, while a separate set of factors cause dissatisfaction. He explained how employees can be well managed at the workplace to foster maximum performance. Hertzberg argued that employee satisfaction and dissatisfaction resulted from two distinct set of factors; motivation and hygiene factors respectively. He called motivation factors, satisfies and hygiene factors, dissatisfies. He did argue that the opposite of satisfaction cannot be dissatisfaction. He brought out the fact that the best way to gratify the higher order needs (motivators/satisfiers) is to provide employees with enriched jobs, as distinguished from tasks that are merely enlarged.

Although Herzberg focused on satisfiers (motivators), he recognized that lower order needs, which he called dissatisfies or hygiene factors, were also important; every supervisor must ensure their satisfaction by providing sound 
education policy. Education policy and administrative procedures, supervisors and managers must be equipped with technical and human relation skills, acceptable working conditions, competitive salaries and wages and harmonious interpersonal relations at the workplace. Improving those lower order needs from a basic acceptable level may not be productive, but permitting them to deteriorate will cause morale and performance problems.

Hygiene factors are necessary and important to establish a level of satisfaction with an employees' work and if any of them were absent or underserved they could act to de-motivate employees and undermine morale. According to Hertzberg, motivators relate to actual performance of the work and these were; responsibility, recognition, promotion and achievement .while Hygiene relate to work environment such as supervision, pay education policies, relationship with colleagues and working condition. Though the hygiene factors are important, they cannot serve to drive employees to higher performance. Hertzberg argues that those factors in the motivators' category were actually what could serve to inspire employees to higher performance.

Strength of the Hertzberg's Motivation-Hygiene theory is that the theory does not emphasize the use of money as factor for motivate teachers, it is rather a hygiene factor. This theory can be used in a school where money is treated as secondary because factors like job promotion, recognition, relationships between employees are considered to be motivating factors rather than money. Moreover, the majority of school management thinks that giving salary is enough for the satisfaction of employees, but when a school board decided to use this theory than only it comes to know about employees' problems and by making sure that factors which dissatisfy employees can be reduced and school can make the environment of the school employee friendly.

Weakness of the Hertzberg's Motivation-Hygiene Theory is that the theory is not free from bias as it is based on the natural reaction of employees when they are enquired the sources of satisfaction and dissatisfaction at work. They will blame dissatisfaction on the external factors such as salary structure, education policies and peer relationship. Also, the employees will give credit to themselves for the satisfaction factor at work. Despite of the weakness, the Hertzberg's Motivation-Hygiene theory can be applied in any education institution since the theory emphasis on motivation from within the employees themselves rather than focusing on other external factors. Applying this theory in the educational practices, it can be said that educational managers and administrators need to understand that apart from making available motivators for their subordinates, they must equally ensure that they put in place the hygiene factors because, even though their presence do not motivate, their absence will limit the output of staff. In summary, there will be job dissatisfaction in the absence of hygiene, but there will be no job satisfaction in the absence motivators.

\subsection{Empirical Literature Review}

In Pakistan, a study was conducted by Nawaz and Yasin (2015) on the determinants of motivation among teachers in private secondary schools in Bawahapur Pakistan. Using questionnaires and interview guides, the study found out that teachers are motivated by unbiased appraisals positive behaviour of students, good environment, availability of learning resources and autonomy given to teachers. The study by Nawez and Yasin has shown some of the practices which can lead to teacher motivation. The study has shown that teachers can be motivated by both monetary and nonmonetary incentives. However, the study has not revealed the extent to which the school management, the community or the government perform such practices so as to improve teachers' level of motivation. Moreover, the study was conducted in private schools in which decisions can be made by specific individuals.

In West Africa, Apolline (2014) carried out a study on the motivational strategies used by heads of schools in the management of schools in Fako Division of the Southwest Region of Cameroon. The study adopted descriptive survey design whereby the sample of the study was 10 heads of schools and 52 teachers who responded to questionnaires. The findings revealed that motivational strategies of heads of schools include those related to empathetic, supportive, caring and just on academic and disciplinary matters; positive leadership characteristics behaviours and transformational leadership style. Findings from the study by Apolline also show different practices by the head of school which can contribute to teachers' level of motivation. Despite the fact that the head of school oversees all the school activities, most of the implemented activities are planned passed on by the school board.

Another study in West Africa was conducted by Onuma (2016) about school management support practices for enhancing teachers' performance in secondary schools in Nigeria. The study adopted survey research design and targeted heads of schools and teachers with a sample of 1803 selected using proportionate random sampling techniques. Questionnaire was used as research instrument for data collection. The findings showed that school management lacked administrative and supervisory skills; as a result entrusted academic supervision in the hands of external supervisors. Lack of administrative skills and need for external supervisors by the heads of schools decrease teachers' level of motivation. Though the study by Onuma has pointed out that heads of schools lack some essential skills for them to motivate teachers, it remained silent on whether proper motivation strategies are planned in the schools. In the Tanzanian education system, the school board is responsible for planning and approving most of the school activities including teacher motivation schemes.

In Kenya, a study was conducted by Yula (2016) to assess the influence of board of management members' motivational practices on teachers' retention in public secondary schools in Athi River Sub County. Correlational research design was used whereby teachers and board management members were targeted. The study sample consisted of 60 teachers and 21 board management members. Questionnaires were used to collect data from both the teachers and board management members. The study found out that teachers were not given monitory incentives for extra work they do. Also, teachers reported low provision of nonmonetary incentives; inflexible working schedule and little room for career development. Failure of the management board to provide different forms of motivation makes the teachers to feel unmotivated and hence leading to low rates of teacher retention. The study by Yula (2016) has shown that teachers in 
Kenya feel not to be motivated by the management board. However, the findings left a gap for another study to be conducted due to two reasons; the first one is that the study used only questionnaires which are limited to the perceptions of the respondents. Therefore, the findings may be affected the emotional and personal characteristics of the respondents. Secondly, the study was conducted in Kenya whereby the education policy is not similar to the one in Tanzania; similarly, the school management structure in Tanzania is different from the one in Kenya.

Another study in Kenya was conducted by Martha (2015) on the influence of board of managements' motivational strategies on teachers' job performance in public secondary schools in Kakamega County. This was a descriptive study which used questionnaires to collect data from 115 teachers and 62 Board of management members. The findings showed that decision making for provision of monetary incentives, provision of teaching/learning resources, and involvement of teachers in school board improve teachers working performance and recognition of teachers' job achievements by school board improves teachers' job performance. The study by Martha has shown some of the practices by the school board which are perceived by teachers to contribute to their level of motivation. Moreover, no documents were analyzed during data collection process to determine whether the information given by the members of management board reflects reality. In Tanzanian context, Musa (2014) did a study about the role of school leadership in motivating teachers in Ilala Municipality Dar es Salaam. The study employed descriptive survey design and targeted teachers and heads of schools. Questionnaires and interviews were used to collect data from 120 teachers from 20 schools in Ilala municipality. The results of the findings have revealed that school-based factors leading to teacher motivation included conducive environment, parents' involvement in school issues and learners' discipline. Most of the motivation factors identified by the study of Musa are managed by the school board. The school boards in Tanzania are the highest decision-making organs at the school level. However the study did not indicate how the school board gets involved in the matters related to students' discipline and parental involvement in school activities.

Another study in Tanzanian context was conducted by Chua and Mosha (2015), about the managing school internal mechanisms for performance improvement in secondary education. This was a case study involving six secondary schools in Eastern Zone in Tanzania. The sample size was 90 respondents, which included District Secondary Education Officers (DSE0), Secondary School Inspectors, Heads of Schools, teachers, students, and representatives of the School Boards. Findings revealed that, performance of schools was mainly attributed to the kind of management available in a particular school, which will ensure availability of workable and agreed on mechanisms of providing effective teaching and learning. Though the study by Chua and Mosha included school board representatives in the sample, still the findings may not be generalized to other parts of the country. This is due to the fact that a case study being one of the qualitative studies is not generalizable to other settings.

In the United States of America, Shepherd (2018) conducted a study to investigate the relationship between teacher motivation and principals' leadership styles in Alabama through online survey taken by 450 teachers. Results from a survey indicated that heads of schools' leadership styles were significantly related to the combined dependent variables of teacher autonomy, relatedness, competence, and social isolation. Specifically, the results of post hoc tests indicated that teachers reported higher levels of autonomy, relatedness, and competence under a principal who was perceived to demonstrate a democratic leadership style. Moreover, administrators who were interviewed shared ways in which they supported teachers' autonomy, relatedness, and competence in addition to other motivational strategies. The study in the USA by Shepherd has shown the importance for heads of schools to be skilled on different motivational strategies and use suitable leadership styles that will motivate teachers. The use of leadership styles that encourage involvement of teachers makes the teachers to feel valued and hence increases their level of motivation.

Paramboor, et al (2015) conducted a study on teachers' perception of the role of school administrators in motivating high school teachers in Kerala, India. This was a descriptive study whereby a maximum of 40 teachers were selected from 10 schools through simple random sampling technique. The sampled teachers responded to a questionnaire which was developed after a thorough review of literature. The findings demonstrated a positive relationship between teachers' level of motivation and their job performance whereby low motivation among teachers affected their job performance negatively. The study also found out that both male and female teachers of any teaching qualification need to be motivated. The study by Paramboor, et al has shown the importance of motivating teachers regardless their gender or academic qualifications. According to the findings, male and female teachers are to be motivated, moreover, certificate, diploma and graduate teachers also need to be motivated for them to stay longer and give their best in the teaching profession. The study however has not shown what kinds of motivation strategies are practiced in the schools. Nevertheless, the study has not provided information about the involvement of school boards on motivating teachers.

In African context, a quantitative study was conducted by Mphale (2014), about the leadership capability model for motivating junior secondary school teachers in Botswana. The study adopted quantitative research paradigm under which cross sectional research design was used. Questionnaire as research instruments were used to collect data from the field. The findings of the study revealed that there is no specific leadership model used by the senior management in schools. The study findings also revealed that whichever leadership model that could be used in schools, senior management ought to be confident, competent and self- managing in order to motivate staff effectively. The findings by Mphale in Botswana are contrary to what was observed in the USA by Shepherd (2018); thus, leaving a dilemma whether the relationship exists or not. The difference in the findings might be attributed by the methods of data collection used in the two studies. Both studies used questionnaires which the researchers could not have control on the people filling them. Therefore, the provided information may not be consistent.

In Tanzanian context, Mark (2015), did a study on the factors influencing teachers' motivation and job performance in Kibaha District. The study employed a descriptive survey research design and the data were collected from 39 respondents using questionnaires and interviews. Research techniques employed were interview and questionnaire. 
The findings of the study show that motivation of teachers was affected by factors such as poor working conditions, low salary/pay, unfavourable policies on education, delays in promotions and community's negative perception towards teaching. One of the responsibilities of the school board is to plan and support the implementation of teacher motivation strategies. However, the study by Mark has not identified how the school board within the area of study motivates teachers. Therefore, there was a need for a study to be conducted to investigate the perceptions of teachers on how the school board contributes to their levels of motivation.

\section{Methodology}

The researcher adopted concurrent design under the mixed methods approach which enabled her to collect qualitative and quantitative data at the same time for the purpose of understanding the problem in detail. The study targeted 56 heads of schools, 1110 teachers and 672 board members form community secondary schools in Moshi District Council. From the target population, probability and nonprobability sampling techniques were used to select the study sample which consisted of 100 teachers, 10 heads of schools and 10 members of school boards to make a total number of 120 respondents.

Questionnaires, document analysis schedule and interview guides were used to collect the necessary data to address the research problem. Questionnaires were distributed to teachers while the heads of schools and members of the school boards were interviewed. The researcher also analysed documents from the head of schools office relating to functions of the school boards especially teacher motivation. Descriptive and inferential statistics were used to analyse the quantitative data in terms of frequency, percentage and mean scores with the aid of SPSS. The hypothesis was tested using independent sample t-test at 95\% confidence level. Tables and charts were used to present the quantitative data.

For the case of qualitative data, thematic analysis was conducted where the emerging issues from the interviews were categorized into theses according to research questions and the presentation was done in words with the support of direct quotations. The researcher adhered to the ethical considerations in research by ensuring confidentiality and anonymity as well as protecting all participants from any harm during the entire research process.

\section{Findings}

\subsection{Extent to Which the School Boards Perform Different Activities to Enhance Teachers' Level of Motivation}

The first research question aimed at finding the extent to which the school boards perform different activities to enhance teachers' level of motivation. Responses from teachers, heads of schools and school board members were used to answer the question. Additionally data from document analysis guides were supplemented the responses from teachers, heads of schools and school board members. Table 1 summarizes the responses from teachers on whether the school board perform different motivation practices.

\begin{tabular}{|c|c|c|c|c|c|c|}
\hline Motivation Activity Done By School Board & \multicolumn{2}{|c|}{ Always } & \multicolumn{2}{|c|}{ Sometimes } & \multicolumn{2}{c|}{ Never } \\
\cline { 2 - 7 } & $\mathbf{f}$ & $\mathbf{\%}$ & $\mathbf{f}$ & $\mathbf{\%}$ & $\mathbf{f}$ & $\mathbf{\%}$ \\
\hline Issuing certificates of excellence to teachers & 9 & 9.0 & 22 & 22.0 & 69 & 69.0 \\
\hline Facilitating annual trips for teachers & 1 & 1.0 & 24 & 24.0 & 75 & 75.0 \\
\hline Attending to teachers' problems & 10 & 10.0 & 48 & 48.0 & 42 & 42.0 \\
\hline Recognizing teachers' performance & 16 & 16.0 & 51 & 51.0 & 33 & 33.0 \\
\hline Providing meals for teachers at school & 7 & 7.0 & 22 & 22.0 & 71 & 71.0 \\
\hline Apprizing best performing teachers & 11 & 11.0 & 26 & 26.0 & 63 & 63.0 \\
\hline Inviting guest speakers to talk with teachers & 5 & 5.0 & 29 & 29.0 & 66 & 66.0 \\
\hline Ensuring positive teaching environments & 10 & 10.0 & 53 & 53.0 & 37 & 37.0 \\
\hline Supporting teachers with different challenges & 8 & 8.0 & 27 & 27.0 & 65 & 65.0 \\
\hline Discussing with teachers on motivation matters & 11 & 11.0 & 37 & 37.0 & 52 & 52.0 \\
\hline
\end{tabular}

Table 1: Teachers Response on the Extent to Which School Boards Do Motivate Them

Source; Field Data (2021)

Data in table 1 generally show that most of the teachers who responded to this question indicated that the school boards never perform most of the motivation activities. For instance, according to the table, $75 \%$ of teachers indicated that the school boards never facilitate annual trips for teachers, $24 \%$ indicated that the school boards sometimes facilitates their annually trips and only 1\% of the teachers indicated that the school boards always facilitates annually trips. This implies that most of the teachers considered the school boards not facilitate annul trips. Similar findings were observed from the analysis of documents whereby out of ten visited schools, the analyzed documents of only four schools indicated the facilitation of annual trips for teachers at least once in three years. Similarly, during the interviews, only one head of school indicated that the school board has accepted a budget for teacher trips outside the school. This is what the head of school ' 1 ' said;

I remember to have taken teachers for trips one in the five years I have been the head of this school. It is only one time the school board passed a budget for teacher trips. I may not have much to say but I think it is important for teachers to be taken for trips outside the school (HOS1; Personal Interview 20 $0^{\text {th }}$ May, 2021).

Information from teachers, the heads of schools and document analysis suggest that the facilitation of annual trips as a motivation for teachers is rarely done in most of the schools. According to the equity theory by Adams (1963), people 
value fair treatment which causes them to be motivated. Therefore, facilitating annual trips for teachers can be a motivating factor for teachers to refresh and therefore making them to enjoy being in the teaching profession. Failure of the school board to facilitate annual trips demotivates teachers.

Data in table 1 also show that $71 \%, 22 \%$ and $7 \%$ of teachers indicated that the school boards never, sometimes and always provide meals for teachers at schools respectively. This implies that majority of teachers considered the school boards not to provide meals for teachers at schools. Similar findings were observed from the analysis of documents whereby no data on teacher meals were observed in six out of the ten visited schools. This means that in the four schools, there was no budget set for school lunch to teachers. Data from interview with heads of schools and school board members also showed that meals are not provided in all the schools. For instance, the head of school ' 2 ' had the following to say.

To some extent the school board contributes to teacher motivation like providing meal equipment. Hence the school board contributes to teacher motivation through to teacher motivation through providing lunch and tea (HOS2; Personal Interview 21 ${ }^{\text {st }}$ May, 2021).

These responses suggest that the provision of lunch to teachers in schools is not evenly done across the schools in Moshi District Council. Teachers in some schools are provided with food while others in other schools are neither given lunch nor tea. Based on the hierarchy of needs theory by Maslow (1954), food being one of the psychological needs should be met for teachers to strongly desire the higher needs. Therefore, providing food to teachers makes them to feel supported, cared and valued and thus they are likely to demonstrate their best performance in the teaching profession. Since most of the community secondary schools in Moshi District Council are day schools whereby most of them do not have teacher houses around, providing meals to teachers can act as a strong motivation for them to work for the whole day as supported by Apolline (2014) who put forward that empathetic, supportive and caring cause motivation to teachers.

Moreover, data from table 1 shows that 69\%, 22\%, and 9\% of teachers indicated that the school boards never, sometimes and always issue certificates of excellence to teachers respectively. This implies that most of teachers are not given certificates of excellence when despite showing brilliant performance. Responses from teachers agree to what was observed from the analysis of documents whereby out of the ten visited schools, documents from only two schools indicated that teachers are motivated by giving them certificates of appreciation based on the form four national examination results. Similarly, only two heads of schools out of the interviewed ten acknowledged that teachers are provided with certificates of appreciation. For instance, the head of school ' 1 ' said;

Other award is certificate of appreciation to the best performing teachers after the release of national form four examinations. The poor performing teachers are also required to give reasons in writing and to indicate how they are going to perform better next time (HOS1 personal interview, 20 th May, 2021).

Responses from teachers, heads of schools and data from document analysis generally indicated that teacher motivation by offering certificates of appreciation is rarely done. Failure of issuing certificates of excellence shows that the school boards do not recognize the efforts made by teachers in the teaching profession. This may make the teachers to fell unvalued and hence their commitment to the teaching process may be negatively affected. This is supported by Chuwa and Mosha (2015) who showed that recognizing teachers' good performance motivates teachers to put more efforts in the teaching profession and therefore the teaching process will be improved leading to better students' academic achievements.

Furthermore, data in the table 1 show $66 \%$ of teachers indicated that school boards never invites guest speakers to talk with teachers. This implies that most of the teachers who took part in the study considered the school boards not to invite guest speakers to come and talk with teachers on the view of motivating them. Data from the analysis of documents also showed that only in one school out of the visited ten a guest speaker had been invited to talk to teachers, students as well as parents. No head of school during an interview indicated the invitation of guest speakers at the respective school specifically to talk with teachers. This also indicates that this motivation practice in not used in most of the schools in Moshi District Council. Inviting guest speakers to talk to teachers can make the teachers air out their challenges and learn new skills which will make them to be better adapted in the teaching profession. This is in agreement to Leor (2015) who pointed out that guest speakers are great tools for motivating workers leading to improvement, commitment and performance. As long as the school boards are responsible for motivating teachers, it could be of great value for it to invite guest speakers to talk to teachers on different topics related to the teaching profession. Failure of the school board to invite guest speakers to talk with teachers on different matters makes the teachers not to learn new skills which could make them to be motivated to continue being in the teaching profession.

Also data in table 1 show that $65 \%$ of teachers indicated that the school boards never support teachers' with different challenges respectively. This implies that majority of the teachers who took part in the study consider to be given no any support by the school boards when they face different challenges. From the analysis of documents, also there are no records about the involvement of school boards on helping teachers with different problems. The only thing observed in the documents is taking measure for teachers who demonstrate malicious behaviours. Moreover, during the interviews, neither heads of schools nor school board members stated the role of school board towards helping teachers with different problems. Failure of the school boards to respond to the challenges of teachers leads to demotivating teachers since these teachers may feel not being cared by and therefore their teaching morale goes down. As teachers develop low morale in the teaching profession, they become less committed and demotivated. This low teaching morale and demotivation becomes even high if they see that the school boards does not care about the difficulties they go through and hence affecting their job performance and therefore leading to poor students' academic performance as noted by Mbope (2015) that teacher demotivation negatively affects the teaching profession leading to poor learning outcomes among students. 
Data in table 1 also show that $63 \%$ of teachers indicated that the school boards never apprize the best performing teachers. This implies that majority of the teachers considered the school boards never to apprize them when they demonstrate excellences in performance. However, data from document analysis showed that teachers in eight out of the ten visited schools are given momentary incentives based on students' performance in the national examination. In most schools, teachers are given ten thousand shillings for any ' $A$ ' grade, five thousand shillings for any ' $B$ ' grade and three thousand for any ' $C$ ' grade. Moreover, all the interviewed heads of schools reported to be providing monetary incentives for teachers who demonstrate excellences for instance the head of school '3) said;

The board has approved a budget for awarding teachers, whose subjects perform well in national examinations (HOS3; personal interview 24th May, 2021).

Looking at the responses from teachers, heads of schools and data from document analysis, there is deference. The difference between the responses by teachers and what is said by head of schools together with data from document analysis suggested that though plans are set for teacher motivation, such plans are not achieved since most of the teachers are not motivated. Also the difference suggest that the amount of money set for teacher motivation is not considered by most of the teachers to be less motivate enough when compared to the efforts they put in the teaching process. Failure of the school boards to apprize the teachers when they show good performance may demotivate these teachers to the extent that they may not see the importance of them using much of their energy to achieve the best performance. On the contrary, if teachers are apprized on the basis of their performance, they may become highly motivated and therefore are likely to perform better and better. Apprizing the best performing teachers challenges other teachers to work hard so that next time they can be awarded. This is further supported by Nyakundi\&Ruburu (2019) who put forward that appraisal to the best performing teachers is a good way of motivating teachers and may lead to excellences in the teaching profession.

Generally, data from table 1 majority of teaches (more than 60\%) indicated never to most of motivating practices. This means that school boards does too little when it comes to teacher motivation. Lack of essential skills and warmness on their roles among members of school boards may be among the factors for such failure (Remijan, 2014). The researcher also analyzed school documents to determine information related to teacher motivation. She got access to files in all the ten sampled schools whereby she looked for kinds of motivation practices recorded and the number of teachers motivated for the past three years. Data from document analysis has been summarized in table 2 .

\begin{tabular}{|c|c|c|}
\hline School Code & Motivation Practices Recorded & Number of Teachers Motivated \\
\hline School A & $\begin{array}{ll}- & \text { Providing meals to teachers } \\
- & \text { Cash money during graduations } \\
\text { - } & \text { Get together party } \\
\end{array}$ & 25 \\
\hline School B & $\begin{array}{ll}- & \text { Incentives to teachers } \\
\text { - } & \text { Holding meetings with teachers }\end{array}$ & 16 \\
\hline School C & 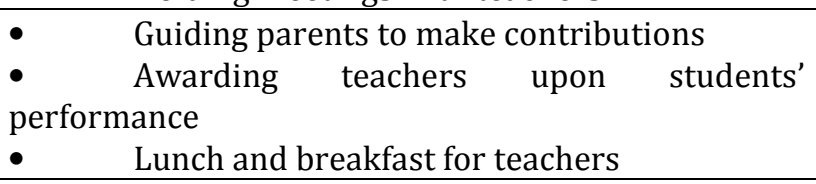 & 10 \\
\hline School D & No any motivation at all & - \\
\hline School E & $\begin{array}{ll}- & \text { Tours outside the school } \\
\text { - } & \text { To influence parents to contribute } \\
\text { - } & \text { Monetary incentives }\end{array}$ & 10 \\
\hline School F & $\begin{array}{l}\text { - } \quad \text { Providing meals to teachers } \\
\text { - } \quad \text { Providing awards for higher performance of } \\
\text { students } \\
\text { - } \quad \text { Lunch and breakfast for teachers }\end{array}$ & 32 \\
\hline School G & $\begin{array}{ll}- & \text { Trips outside the school } \\
\text { - } & \text { Rewards to teachers } \\
\text { - } & \text { Certificates of appreciation } \\
\end{array}$ & 14 \\
\hline School H & No records of motivation at all & _ \\
\hline School I & No any record of teacher motivation & - \\
\hline School J & $\begin{array}{ll} & \text { Building teachers' houses } \\
\text { - } & \text { Get together party } \\
\text { - } & \text { Awarding the best performing teachers }\end{array}$ & 23 \\
\hline
\end{tabular}
Source; Field Data (2021)

Data in table 2 show that the provision of meals to teachers at schools was done and recorded in the documents of three schools out of the sampled ten. These findings are in agreement to what was indicated by teachers whereby most of them $(71 \%)$ indicated not to be satisfied with the meals provided at schools. The most common motivation practice as recorded in the school documents was the provision of monetary incentives to teachers. This practice was recorded in seven out of the ten visited schools. This implies that a momentary incentive is the major motivation practice conducted in most of the community secondary schools in Moshi District Council. These findings suggested that members of the school 
boards are not familiar with other methods of motivating teachers as they highly consider the provision of money to be the outstanding motivation. This makes the motivation practices not to be reliable since sometimes the school do not have adequate budget to achieve such practices. The school boards could use other methods of teacher motivation such as giving certificates of appreciation, words of congratulation and inviting guest speakers to motivate the teachers. These methods are less expensive and can make the motivation practices to be progressive.

Data from document analysis schedule also shows that the number of teachers motivated varies across the schools and years. For instance, school ' $A$ ' had the highest number of motivated teachers (25) for the past three years while school ' $C$ ' and ' $E$ ' had motivated 10 teachers each for the past three years. The difference in the number of motivated teachers may be due to the motivation criteria and the availability of funds for teacher motivation. Table 3 summarized the criteria for teacher motivation and the source of funds.

\begin{tabular}{|c|c|c|}
\hline School Code & Criteria for Motivation & Source of Funds \\
\hline School A & $\begin{array}{ll}\text { - } & \text { Performance in national examinations } \\
\text { - } & 20 \text { thousand shillings for A in any subject } \\
\text { - } & 10 \text { thousand shillings for B in any subject } \\
\text { physics } & 5 \text { thousand shilling for C in mathematics and }\end{array}$ & $\begin{array}{l}\text { - } \quad \text { Every parent to } \\
\text { contribute ten thousands per } \\
\text { year }\end{array}$ \\
\hline School B & Attending remedial classes & $\begin{array}{l}\text { - } 20 \% \text { of the money } \\
\text { collected from self-reliance } \\
\text { activities }\end{array}$ \\
\hline School C & Attending remedial classes & $\begin{array}{llr}\text { Each } & \text { student } & \text { to } \\
\text { contribute twenty } & \text { five } \\
\text { thousands per year } & \\
\end{array}$ \\
\hline School D & No any motivation at all & $\begin{array}{lll}- & \text { No records } & \text { on } \\
\text { teacher motivation } & \\
\end{array}$ \\
\hline School E & Subject performance each year at CSEE results & $\begin{array}{ll}\text { - Contributions from } \\
\text { parents }\end{array}$ \\
\hline School F & $\begin{array}{l}\text { - } \\
\text { - } \\
\text { - }\end{array}$ & $\begin{array}{l}\text { - Each parents to } \\
\text { contribute twenty thousand } \\
\text { per year }\end{array}$ \\
\hline School G & 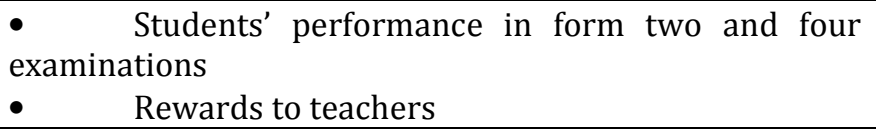 & $\begin{array}{l}-\quad \text { Self-reliance } \\
\text { activities (school projects) }\end{array}$ \\
\hline School H & - $\quad$ No records of motivation at all & $\begin{array}{l}\text { - No record on teacher } \\
\text { motivation }\end{array}$ \\
\hline School I & No any record of teacher motivation & $\begin{array}{l}\text { - No record on teacher } \\
\text { motivation }\end{array}$ \\
\hline School J & $\begin{array}{l}\text { Attending remedial classes } \\
\text { Students performance in national examinations }\end{array}$ & $\begin{array}{l}\text { - Contributions from } \\
\text { parents }\end{array}$ \\
\hline
\end{tabular}

Table 3: Findings from Document Analysis schedule on Criteria for Motivation and Source of Funds Source; Field Data (2021)

Data in table 3 show that schools have set different criteria for teacher motivation. In most of the schools, the performance of students in national examinations is the major factor. Other factors include participation of teachers in remedial classes. Most of the schools depend on contributions from parents as their main source of funds for teacher motivation. However, during the analysis of documents, the researcher observed that some parents do not make the required contributions. Therefore, affecting the rate and frequency of motivating teachers, for instance in school ' $A$ ' the required budget for teacher motivation in 2019 was 88, 7500 Tanzanian shillings but only 20 percent of it was collected from the parents. Hence the motivation process was not achieved as planned.

The researcher also collected information from head teachers on motivation practices performed by the school board. During the interviews, all the heads of teachers indicated to have plans of motivating teachers. Their responses are summarized in table 4.

\begin{tabular}{|c|c|c|}
\hline Motivation Practices & Criteria for Motivation & Frequency of Motivation \\
\hline $\begin{array}{l}- \text { Monetary } \\
\text { incentives } \\
\text { - } \quad \text { Meetings with } \\
\text { teachers and parents }\end{array}$ & $\begin{array}{l}\text { - } \text { Students performance in } \\
\text { national examinations after national } \\
\text { exams } \\
\text { - } \quad \text { The number of students who } \\
\text { score grades A and B }\end{array}$ & $\begin{array}{ll} & \text { Annually } \\
\bullet & \text { Every term }\end{array}$ \\
\hline
\end{tabular}

Table 4: Criteria and Frequency of Teacher Motivation Obtained from Documents

Source; Field Data (2021) 
The major issues raised by heads of schools were the use of monetary incentives and the students' performance in national examinations was identified by the heads of schools as the main factor for teacher motivation. Heads of schools also identified to plan for teacher motivation annually. While responding to a question on motivation practices by the school board on teacher motivation the head of school 'J' said;

Our teachers always need to be recognized and creating good working environment to them when they are at school, this is done sometime by our school board through giving them rewards or appreciating them if their students' academic performances is good to ensure level of teachers' performance is high at this school, However, the practice is not progressive due to lack of funds (HOS4, personal interview 25

Similar information was reported by one of the school board members who said;

We planned to motivate teachers in each year by considering their work performing. Most of motivations are recognition, monetary award, vacation and annual trip. However, we faced several challenges like shortage of funds, lack of cooperation from parents where they are supposed to cooperate financially (HOS5; personal interview $26^{\text {th }}$ May, 2021).

The responses from heads of schools and the members of school boards imply that at some moments the school boards plan for teacher motivations. However, such plans are not always put into practice due to lack of funds. Therefore, school board members are not aware of other methods of teacher motivation as they think of monetary incentives only. Thinking of monetary incentives only affects the progressivity of teacher motivation especially in times when the school boards fail to collect enough funds to facilitate the planned awarding activities.

\subsection{Perceptions of Teachers on School Board Members Contribute to Their Level of Motivation}

The second research question aimed at finding out the perceptions of teachers towards how the school board motivates them. To answer this question, in the questionnaire teachers were provided with 10 perceptions statement and were requested to indicate whether they strongly agree (SA), Agree (A) Undecided (U), Disagree (D) or Strong Disagree (SD) concerning how the school board contributes to their level of motivation. The means scores for each statement were calculated whereby the expected highest mean score was 5 (if all teachers strongly agreed on the statement) and the expected lowest mean score was 1 (if all teachers strongly disagreed on the statement). Because this was a five point scale, mean score above 3 represents positive perceptions, mean score below 3 represents negative perceptions and mean score of exactly 3 indicates no opinion. Teachers' responses on this question are summarized in table 5

\begin{tabular}{|c|c|c|c|c|c|c|c|}
\hline & Statement & SA\% & A\% & U\% & D\% & SD\% & $\begin{array}{l}\text { Mean } \\
\text { Scores }\end{array}$ \\
\hline i. & The school board motivates teachers & 24 & 20 & 8 & 17 & 31 & 2.89 \\
\hline ii. & I am less motivated by the school board & 12 & 25 & 20 & 22 & 21 & 2.85 \\
\hline iii. & $\begin{array}{l}\text { The board of this school does a lot to motivate me } \\
\text { as a teacher }\end{array}$ & 11 & 27 & 14 & 24 & 24 & 2.77 \\
\hline iv. & $\begin{array}{l}\text { Activities done by the school board motivates me } \\
\text { to work hard }\end{array}$ & 6 & 28 & 18 & 25 & 23 & 2.69 \\
\hline $\mathrm{v}$. & $\begin{array}{l}\text { The school board encourages me to be committed } \\
\text { to the teaching profession }\end{array}$ & 5 & 29 & 12 & 34 & 20 & 2.65 \\
\hline vi. & $\begin{array}{l}\text { The motivation by the school board encourages me } \\
\text { to remain in the teaching profession }\end{array}$ & 9 & 21 & 17 & 28 & 25 & 2.61 \\
\hline vii. & $\begin{array}{l}\text { The school board appreciates my efforts and } \\
\text { therefore motivates me to keep working hard }\end{array}$ & 7 & 19 & 16 & 31 & 27 & 2.48 \\
\hline viii. & $\begin{array}{l}\text { Motivation by the school board has improved my } \\
\text { job performance as a teacher }\end{array}$ & 5 & 19 & 16 & 38 & 22 & 2.47 \\
\hline ix. & $\begin{array}{l}\text { As a teacher, I am satisfied with how the school } \\
\text { board motivates teachers at this school }\end{array}$ & 5 & 20 & 17 & 32 & 26 & 2.46 \\
\hline $\mathrm{x}$. & $\begin{array}{l}\text { I am highly motivated by the school meal provided } \\
\text { by the school board }\end{array}$ & 13 & 13 & 8 & 21 & 45 & 2.28 \\
\hline \multicolumn{7}{|c|}{ Average, mean score } & 2.62 \\
\hline
\end{tabular}

Table 5: Perceptions of Teachers on Members of School Boards on Contribution to their Level of Motivation Source; Field Data (2021)

KEY: Strongly Agree (SA), Agree (A) Undecided (U), Disagree (D), Strong Disagree (SD)

According to data in table 5, the mean score perception for teachers on the statement 'the school boardsmotivate teachers' was 2.89. This implies that most of the teachers disagreed with this statement. Therefore, it can be inferred that the boards of community secondary schools do not motivate their teachers. By looking at the mean score (2.89) it is below the neutral score (3) therefore teachers have a negative perception on how the school boards motivates them. Therefore, most of the teachers do consider the current school boards to be changed as long as it does not motivate them. Having this negative perception symbolizes teachers to be dissatisfied by the practices done by the school boards to motivate them. Failure of the school to motivate teachers then leaves these teachers to be demotivated. Teacher demotivation has been found to be directly linked with poor performance of students in internal and external examinations as suggested by Mark (2015) who reported that teachers from poor performing schools have been complaining of being demotivated. 
Data in table 5 also show that the perception mean score of teachers on the stamen that 'I am less motivated by the school board' was 2.85. This implies that more teachers who participated in the study agreed to the statement indicating that they are less motivated by the school boards. The mean score perception of teachers (2.85) is below the natural point (3) indicating that teachers have negative perceptions on the extent to which the school board motivates them. Similar cases were observed in Dodoma region whereby most of the teachers reported to be less motivated (Maganga, 2016). When teachers feel to be less motivated they are likely to quit the teaching profession and those who remain may not be such committed and therefore the quality of education offered in community secondary schools with less motivated teachers is negatively affected. The issue to low motivation among teachers is not observed in Tanzania only but across other countries globally (Salifu, 2014).

The mean score for the statement 'the board of this school does a lot to motivate me as a teacher' was 2.77. This implies that most of the teachers who participated in the study disagreed with the statement. Their disagreement means that the school boards does too little to motivate them as teachers. This leads to teacher demotivation and hence theory work morale is negatively affected. Similar observation were made by Mtondo (2016) who reported that most of the school management organs are more concerned with controlling the teachers instead of encouraging and raising their morale towards the teaching profession. This is also in agreement to Sekiwu (2009) who indicated that low motivation among teachers in highly connected to poor school management. The school boards being the highest organ for decision making in at school levels, it is expected also to come up with techniques which can motivate the teachers.

Concerning the statement the motivation by the school boards encourages me to remain in the teaching profession' the mean score was 2.61. This implies that most of the teachers disagreed with the statement. Their disagreement implies that they consider the school boards not to motivate and encourage them to remain in the teaching profession. Low motivation to teachers by the school boards demotivates them to stay in the teaching profession as a result; there is a high rate of teacher turnover across in the country and across Africa (Herut, 2019; Jeston, 2013). The school board is the immediate organ to which teachers can rely on when faced with challenges and problems in the teaching profession, failure for it to be cooperative and encouraging makes the teachers to have no place to take their concerns and the result they become demotivated. The level of demotivation affects their job performance and may eventually affect the performance of students.

The mean score for the statement 'the school board appreciates my efforts and therefore motivates me to keep working hard' was 2.48. This also implies that a large number of teachers disagreed with the statement. This mean score being less than 3.0 also implies that teachers have a negative view on how the appreciation by the school board despite their efforts they make in the teaching profession. Appreciating individuals' efforts makes them to maintain such good performance and also motivates others to improve (Saraswati et al 2020). Therefore, the school board being the highest organ for decision making is expected to plan different strategies for recognizing teachers performance and by doing so, teachers will be motivated and encouraged to work hard in the teaching process. Generally, the mean score for teachers on all the ten statements was 2.62. This implies that teachers have negative perceptions on how the school board motivates them. Teachers consider the school board not to do most of the activities that are expected to be done for the purpose of motivating teachers.

The researcher further wanted to determine whether male and female teachers have different attitudes towards how the school board motivates them. Therefore, an independent sample t-test was run at the significance level of 0.05 to compare the attitude mean score of male and female teachers so as to determine whether there was a significant difference between them. The results of hypothesis testing are summarized in table 6 .

\begin{tabular}{|c|c|c|c|c|c|c|c|}
\hline \multicolumn{2}{|c|}{} & \multicolumn{2}{|c|}{$\begin{array}{c}\text { Levene's Test for } \\
\text { Equality of Variances }\end{array}$} & \multicolumn{4}{c|}{ t-test for Equality of Means } \\
\cline { 3 - 7 } \multicolumn{2}{|c|}{} & F & Sig. & t & df & Sig. (2-tailed) & $\begin{array}{c}\text { Mean } \\
\text { Difference }\end{array}$ \\
\hline $\begin{array}{c}\text { Mean } \\
\text { Scores }\end{array}$ & $\begin{array}{c}\text { Equal variances } \\
\text { assumed }\end{array}$ & 3.270 & .074 & .807 & 98 & .421 & .13000 \\
\cline { 2 - 7 } & $\begin{array}{c}\text { Equal variances } \\
\text { not assumed }\end{array}$ & & & .807 & 94.251 & .421 & .13000 \\
\hline
\end{tabular}

Table 6: T-Test Outputs

Source; Field Data (2021)

Results of hypothesis testing show that $\mathrm{T}(98)=0.077$ and $\mathrm{p}$-value $=0.421$. Since the $\mathrm{p}$-value $(0.421)$ is less than the significance level $(0.05)$ the null hypothesis is not rejected. This implies that there is no significant differences in the attitude mean scores of teachers and students on how the school board motivates them. Therefore, both male and female teachers in Moshi District Councilfeel to be not motivated by the school boards at the same basis. Such negative perception of teachers on how the school boards motivate them may negatively affect the relationship between teachers and the members of school boards. Such negative perception also implies that both male and female teachers do not consider the school boards to motivate them.

\section{Conclusions}

The school boards do not do most of the practices that would contribute to teachers' level of motivation. Both monetary and non-monetary incentives are done to a little extent. This is due to the fact that teacher motivation is not an agenda in most of the school boards annual meetings. The failure of the school boards to motivate teachers makes these 
teachers to feel less valued and hence their commitment on the teaching profession may be negatively affected. As teachers feel not to be appreciated, they are likely not to put more efforts in teaching and hence students' academic achievement may also be negatively affected.

Teachers perceive that the school board does not contribute to their level of motivation. Such negative perception is due to the fact that the school boards does too little to motivate teachers. Negative perception of the teachers on how the school boards motivate them may negatively affect the relationship between them and the school board members. As the teachers feel not to be motivated by the school boards, they are likely not to cooperate with it on different activities. This lack of cooperation may affect the achievement of school activities and therefore affect the teaching and learning process. Results from hypothesis testing shows that both male and female teachers feel not to be motivated by the school boards ( $\mathrm{p}$-value $=0.421$ ) and therefore the null hypothesis was not rejected.

\section{Recommendations}

Teacher motivation should be an agenda in the annual school boards meetings. Making it an agenda will make the school boards members to see the importance of teacher motivation. Also when teacher motivation is made an agenda in the meetings, different motivation strategies will be discussed and proper mechanisms to ensure that teachers are motivated will be set. The head of schools being the secretaries to the boards should therefore include the teacher motivation in the meeting agenda and not to make it being discussed as an 'any other businesses'.

All forms of motivation to be practiced by the school boards should be consistent and the criteria for motivation should be clearly stated to the teachers. This will make the teachers to see that they are valued by the school boards and therefore improve their perceptions on how the school boards contribute to their level of motivation. Therefore, it is important for the school board to state kinds of motivation to be given and the conditions for teachers to be eligible for such motivation.

The Government through the Ministry of Education should set and send to schools a budget for teacher motivation. This will make the motivation process to be consistent. Additional, the community should be sensitized on the importance of contribution some amounts of money which can be used for teacher motivation. Moreover, the selection of school board members should base on education and experience so that the selected members are aware about teacher motivation.

\section{References}

i. Admassie, S. Z. (2017). Principal Leadership Practices, Teacher Motivation, and Student Achievement in Secondary Schools of Addis Ababa City Government [Unpublished]. Addis Ababa University.

ii. Apolline, A. T. (2014). Motivational Strategies used by Principals in the Management of Schools. The Case of some Selected Secondary Schools in the Fako Division of the Southwest Region of Cameroon [Unpublished]. University of Jyvaskyla.

iii. Chua, C. L., \&Mosha, H. J. (2015). Managing School Internal Mechanisms for Performance Improvement in Secondary Education: Case of Six Secondary Schools in Eastern Zone in Tanzania. SAGE Open, 5(4), 2158244015610172. https://doi.org/10.1177/2158244015610172

iv. Güven, G. Ö. (2013). Challenges in Achieving High Motivation and Performance in Educational Management: Case Study of a North Cyprus Public High School. International Journal of Humanities and Social Science, 3(6), 20-26.

v. Lu, J., \&Hallinger, P. (2018). A Mirroring Process: From School Management Team Cooperation to Teacher Collaboration. Leadership and Policy in Schools, 17(2), 238-263. https://doi.org/10.1080/15700763.2016.1278242

vi. Lyimo, G. E. (2014). 'Analysis of Teachers" Low Payments in Tanzania.'International Journal of Education Research.,2(1), 48-62.

vii. Mathipa, E., Magano, M., Mapotse, T., Matlabe, S., \&Mohapi, S. (2014).The School Management Team Leadership Role in Rural Primary School Setting.Mediterranean Journal of Social Sciences, 5(7), 367-373. https://doi.org/10.5901/mjss.2014.v5n7p367

viii. Mbope, N. A. (2015). The Impact of Teachers' Motivation on the Improvement of the Quality of Teaching and Learning in Public Primary Schools in Ilala District, Tanzania [Unpublished]. The Open University of Tanzania.

ix. Melchiory, D. (2015). The Role of School Management on Teacher Motivation in Tanzania: A Case Study of Two Selected Public Secondary Schools in Nyamagana District. Mzumbe University.

x. Mphale, L. M. (2014). Leadership Capability Model for Motivating Junior Secondary School Teachers in Botswana. International Research in Education, 2(1), 186-199.

xi. Mukumbi, M. M., \&Kabeta, R. M. (2019).Influence of Head Teachers' Motivational Practices on Teacher Performance in Public Secondary Schools of Chililabombwe District- Zambia.International Journal of Humanities Social Sciences and Education (IJHSSE), 6(9), 117-125.

xii. Musa, J. (2014). Role of school Leadership in Motivating Teachers: ACase of Ilala Municipal, Dar essalaam [Published]. Open University of Tanzania.

xiii. Okorie, U. A., \&Usulor, V. I. (2016).Analysis of Principals' Motivational Practices for Teachers Effectiveness in Public and Private Secondary Schools in Ebonyi State, Nigeria.Public Policy and Administration Research, 6(2), 74-83.

xiv. Onuma, N. (2016). Principal's Management Support Practices for Enhancing Teachers' Performance in Secondary Schools in Nigeria. International Journal of Education, Learning and Development, 4(3), 26-36. 
xv. Raynham, C. L. (2016). School Management Teams' motivation of teachers in inclusive classrooms [Dissertation, University of Pretoria]. https://repository.up.ac.za/handle/2263/60975

xvi. Remijan, K. W. (2014). Improving Teacher Motivation In Secondary Schools with Hybrid Positions. American Secondary Education, 42(3), 30-38.

xvii. Sava, L. A., \&Orodho, A. J. (2014). Socio-economic factors influencing pupils' access to education in informal settlements: A case of Kibera, Nairobi County, Kenya. International Journal of Education and Research, 2(3), 116.

xviii. Scott, P.A. (2013) Examination of Teacher in work place satisfaction and student AchievementElectronic thesis and Dissertation paper 252.

xix. Srivastava, N., \& Bhatia, P. (2013). A Qualitative Study of Employee Motivation Factors in National Banking Sector Of India. International Journal of Business and Management Invention, 4(2), 8-22.

xx. Süleyman, C. (2015). Factors motivating teachers working at elementary and secondary schools in Turkey.Procedia - Social and Behavioral Sciences, 174(11), 3087-3093.

xxi. Their School Improvement Plans: An Action Learning Approach. South African Journal of Education, 34(3). https://eric.ed.gov/?q=school+management+team+on+motivation+\&id=EJ1135546

xxii. URT (1978). Act Supplement; The National Educational Act No 25 Dar Es Salaam. The Government Print

xxiii. URT (1995). EDUCATIONAL TRAINING Policy, Ministry of Education and Culture Dar Es Salaam, The Adult Education Press.

xxiv. URT (1998). Whole School Development Plan. A Manual for Primary School in Tanzania Dar Es Salaam, Ministry of Education and Culture.

xxv. Van Der Voort, G., \& Wood, L. (2014).Assisting School Management Teams to Construct.

xxvi. Yula. I S. (2016). Influence of Board of Management Members' Motivational Practices on Teachers' Retention in Public Secondary Schools in Athi River Sub County, Kenya. University of Nairobi. 